\title{
Strepsiptera species in Estonia
}

\author{
Villu Soon, Tõnu Kesküla \& Olavi Kurina*
}

Soon, V., Kesküla, T. \& Kurina, O. 2011: Strepsiptera species in Estonia. Entomol. Fennica 22: 213-218.

Data on Strepsiptera species in Estonia are presented for the first time. Four species from three families - Elenchus tenuicornis (Kirby, 1815), Halictophagus silwoodensis Waloff, 1981, Halictoxenos tumulorum Perkins, 1918 and Stylops melittae Kirby, 1802 - have been recorded. Collection data and colour photographs for each species are presented and their known distribution and biology briefly discussed. A key to species in Baltic countries and Fennoscandia is provided.

V. Soon, Institute of Ecology and Earth Sciences, University of Tartu, Vanemuise 46, EE-51014 Tartu, Estonia \& Museum of Zoology, University of Tartu, Vanemuise 46, EE-51014 Tartu, Estonia

T. Kesküla \& O. Kurina (*corresponding author), Institute of Agricultural and Environmental Sciences, Estonian University of Life Sciences, Riia 181, 51014 Tartu, Estonia; Corresponding author's e-mail: olavi.kurina@emu.ee

Received 13 September 2011, accepted 27 October 2011

\section{Introduction}

Members of the order Strepsiptera display highly peculiar morphology and lifestyles. They are small to medium sized insects (1.0-7.5 mm long) exhibiting extreme sexual dimorphism (Kinzelbach 1971, Kathirithamby 1989). Free living and flying males have twisted hind wings, while their fore wings are reduced to club-like appendages. Usually endoparasitic and wingless females are known to colonize members of seven insect orders (see reviews by Kathirithamby 1989, 2009). Approximately 600 Strepsiptera species are known to exist globally (Kathirithamby 2002, Kinzelbach \& Pohl 2003), while 30 species from 7 families are known in Europe (Pohl 2010, J. Kathirithamby, pers. comm.). The most comprehensive key to the European species was provided in the monograph by Kinzelbach (1978). For identification of species, however, additional literature (e.g. Waloff 1981) should be consulted.
In Estonia, no exact data on Strepsiptera species have been published previously. Yet, several authors (e.g. Maavara 1956, Elberg 1995, J. Luig unpubl.) have noted the probable occurrence of Strepsiptera in Estonia without referring to species names. Vilbaste (1958) recorded leafhopper specimens parasitized by Strepsiptera in samples from several bogs in Estonia, but did not report species names. By contrast, the order is well studied in neighbouring Finland. Pekkarinen and Raatikainen (1973) published a review with information on six species from Eastern Fennoscandia (including five species from Finland). Three species have been recorded from Sweden and Norway, and three and one species from North-western and Northern parts of European Russia, respectively. There is no information on Strepsiptera in Lithuania (Pohl 2010), but there are unpublished data about two species in Latvia (cf. http://leb.daba.lv/Strepsiptera.htm).

The current study was initiated following re- 
cent findings of several Strepsiptera species in Estonia that necessitated a revision of available information and material from the country. The aim of this communication is to present the novel information on Estonian Strepsiptera species, accompanied by voucher specimen data and colour photographs, and to provide a key to the species, including these in the adjacent areas.

\section{Material and methods}

The specimens were collected from five localities using insect net, yellow pan trap or Malaise trap. The most frequently visited localities were Kalmistu outcrop and a clearing in the Scots pine forest in Ihaste, both in the Tartu area. These areas have partly exposed sandy soil and with rich soilnesting bee and wasp faunas, including large populations of Andrena vaga Panzer, 1799. The specimens of Elenchus tenuicornis were collected within the Estonian Malaise traps project (20082011) using a Czech type trap (cf. http://www. entosphinx.cz/).

Most of the studied material is pinned, but several specimens are preserved in alcohol. The collection and preservation methods for each specimen are described in the studied material below. Habitus photos (Figs. 1a-f, 2a,b) were taken using a Canon EOS7D camera fitted with Canon MP-E65 (F2.8 1-5 $\times$ ) or Canon EF $100 \mathrm{~mm}$ (1:2.8) lenses. The illustration of the male cephalotheca of Halictoxenos tumulorum (Fig. 2c) was combined using Helicon Focus 4.7 software, from several partly focused images taken with a Leica DFC295 camera attached to an Olympus CX31 compound microscope. Morphological terminology follows that of Kinzelbach \& Pohl (2003).

The material has been deposited in the private collection of Villu Soon (VS) and in the IZBE (entomological collection of Institute of Agricultural and Environmental Science, Estonian University of Life Sciences, former Institute of Zoology and Botany). All specimen data have been added to the database of Estonian animal collections (Abarenkov et al. 2010, see also http:// elurikkus.ut.ee/collections.php?lang=eng) and are searchable using the voucher number or species name. Higher systematics of host species fol- lows the Fauna Europaea database (cf. http:// www.faunaeur.org).

\section{Estonian species}

\subsection{Elenchidae}

Elenchus tenuicornis (Kirby, 1815) (Fig. 1e)

Material: $2 \hat{\jmath} \hat{\jmath}$, Hiiumaa Island, Kerema, $58^{\circ} 53$ '26,59'N $022^{\circ} 56^{\prime} 52,57^{\prime \prime} \mathrm{E}$, Malaise trap, 30.VI.-16.VII.2010, R. Miller leg. [IZBE0199001 and IZBE0199002, in alcohol].

Recorded widely in Europe and extending to the Near East (Pohl 2010).

The species has been found by Kathirithamby (1989) to parasitize 66 species of Delphacidae (Hemiptera). Most commonly parasitizes Javesella pellucida (Fabricius, 1794), an abundant Delphacidae leafhopper in Finland (Pekkarinen \& Raatikainen 1973), also common and widespread in Estonia (Vilbaste 1971). The known habitat in Estonia is moist Juniperus dominated scrub on Hiiumaa Island, where specimens were captured by Malaise trap. Stylopized Homoptera specimens reported by Vilbaste (1958) were also most probably infested by E. tenuicornis.

\subsection{Halictophagidae}

Halictophagus silwoodensis Waloff, 1981 (Fig. 1f)

Material: $1{ }^{\lambda}$, Sõõru, 58³9'6.78’N 2653' 33.15"E, Malaise trap, 11.V.-01.VI.2011, V. Soon leg. [VS000019, in alcohol].

Recorded from Great Britain (Waloff 1981), Germany (Pohl 2010), the Netherlands (Smit 2007) and Belgium (Henderickx 2007).

The morphological difference from the allied H. curtisi, known only from type material from southern England (cf. Bland 1998), is described and illustrated in detail by Waloff (1981). The species has been photographed by Henderickx (2007, 2008) and Smit (2007). The life history of $H$. silwoodensis has been described by Waloff (1981) and Melber (1989), who found it to parasitize in Ulopa reticulata (Fabricius, 1794). This leafhopper species is widely distributed in Eu- 
Fig. 1. - a, d. Andrena vaga Panzer, 1779 specimens stylopized by a female of Stylops melittae Kirby, 1802.

- b. S. melittae, male.

- c. S. melittae, female.

- e. Elenchus tenuicornis (Kirby, 1815), male. - f. Halictophagus silwoodensis Waloff, 1981, male. Scale bar $=1 \mathrm{~mm}$.
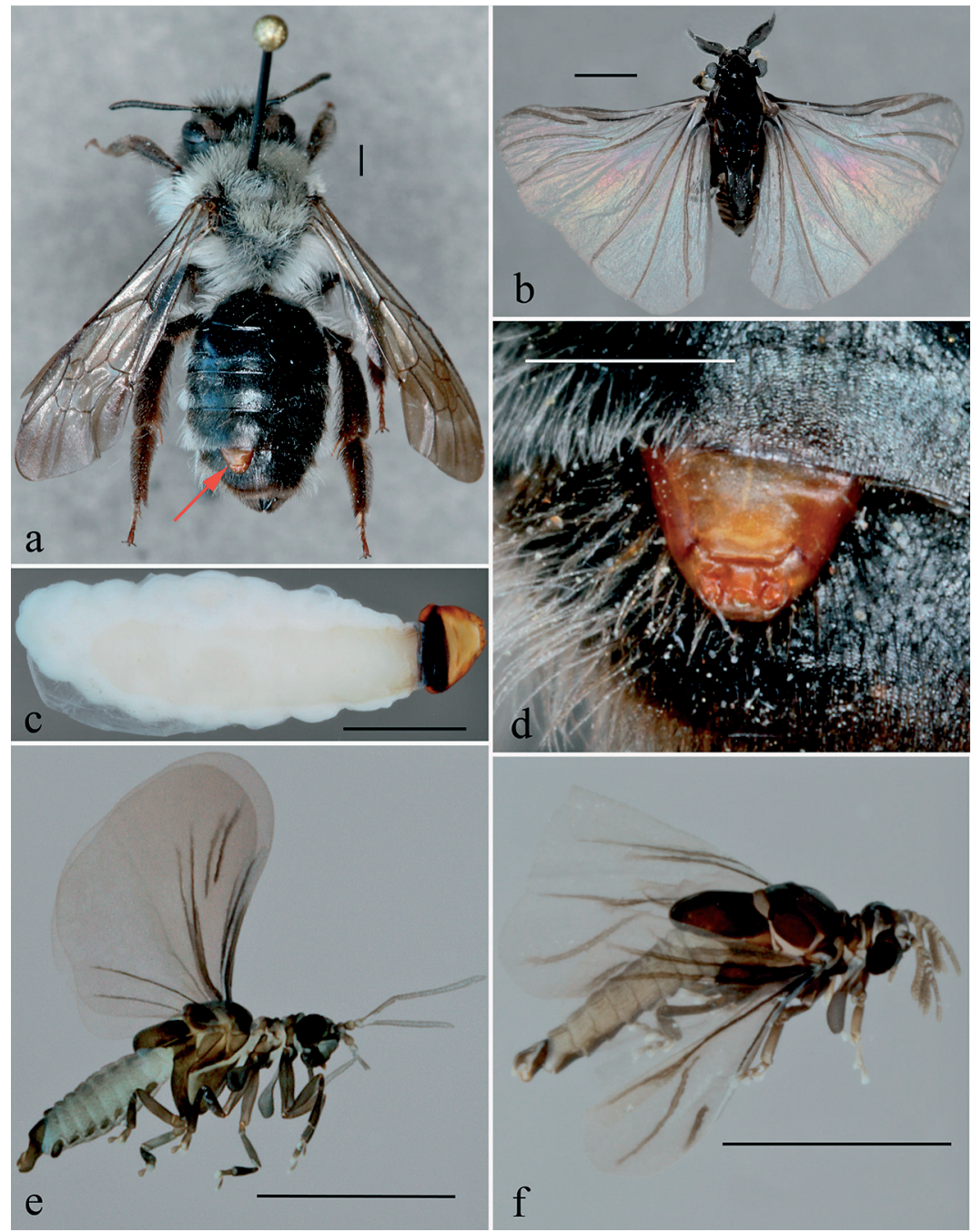

rope including Estonia (Jach 2010). The morphology of the Estonian specimen of $H$. silwoodensis matches well with the description by Waloff (1981) and the figure of the aedeagus provided by Bland (1998). The doubtful $H$. curtisi specimen described by Pekkarinen \& Raatikainen (1973) from Finland possibly belongs to $H$. silwoodensis (cf. Waloff 1981).

\subsection{Stylopidae}

Halictoxenos tumulorum Perkins, 1918

(Fig. 2a, b, c)

Material: Two parasitized Halictus tumulorum (Linnaeus) specimens were collected from

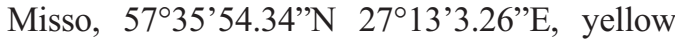
pan trap, 16.VII.2005, V. Soon leg. [VS000017 and VS000018, pinned].

Widely distributed in central and southern Europe, also extending to the Near East and North Africa. In northern Europe, only in Finland and the North-western part of European Russia (Pohl 2010).

According to Kinzelbach (1978), three known European Halictoxenos species are highly specialized parasites of members of Halictus (Hymenoptera: Apidae). Halictoxenos tumulorum is the only known Stepsiptera parasite of the Halictus subgenus Seladonia, including $H$. (S.) tumulorum (Linnaeus, 1758), which is a common and widespread species in Estonia. 

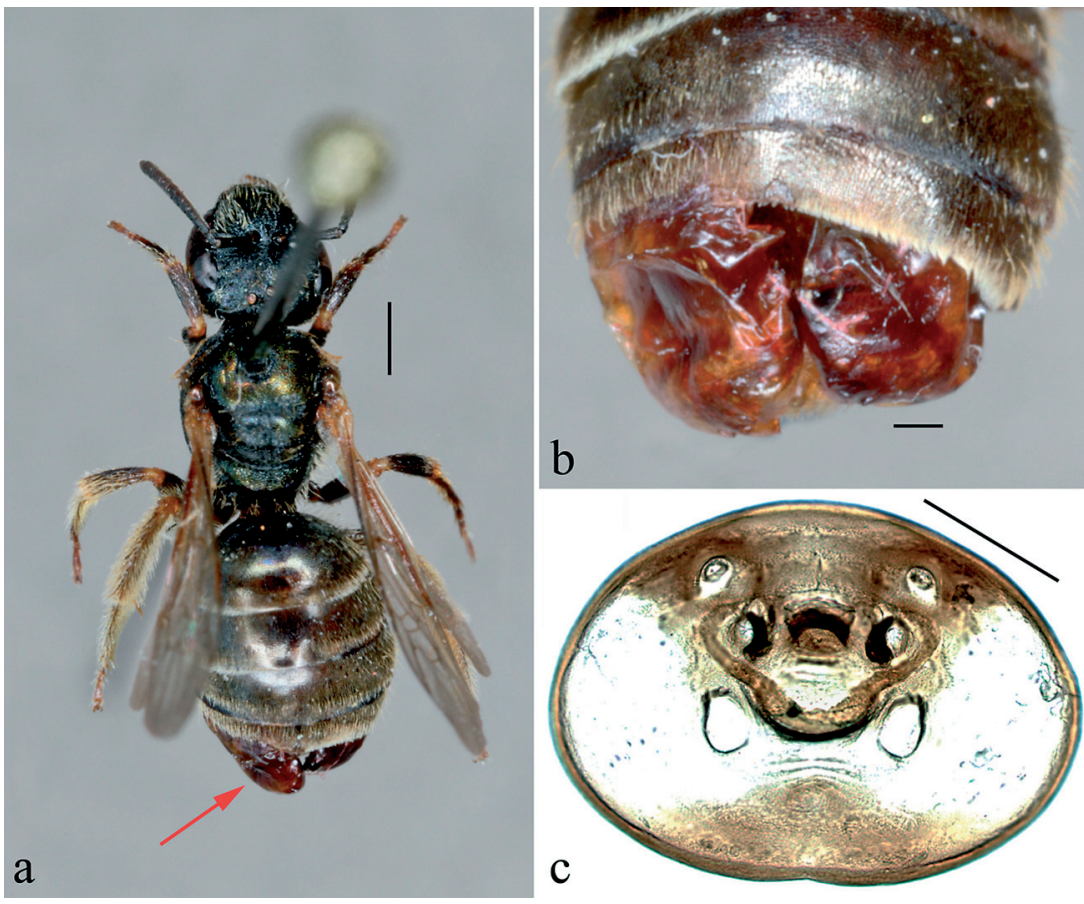

Fig. 2. - a, b. Halictus tumulorum (L.) with male pupae of Halictoxenos tumulorum Perkins, 1918. - c. Halictoxenos tumulorum, male cephalotheca. Scale bar $=1 \mathrm{~mm}(\mathrm{a})$ and $0.25 \mathrm{~mm}(\mathrm{~b}, \mathrm{c})$.
Stylops melittae Kirby, 1802 (Fig. 1a, b, c, d)

Material: $7 \hat{\jmath}$, Tartu, Ihaste, $58^{\circ} 20^{\prime} 56.73^{\prime \prime N}$ 26 46'15.82' E, insect net, 11.IV. and 12.IV. 2010, V. Soon leg. [VS000001 -VS000005, $1 \delta^{\hat{\sigma}}$

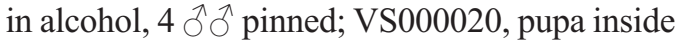
stylopized Andrena vaga, pinned; IZBE0199003,

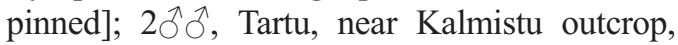
$58^{\circ} 23^{\prime} 42^{\prime \prime} \mathrm{N} 026^{\circ} 42^{\prime} 40^{\prime \prime} \mathrm{E}$, insect net, 25.III. 2000 and 5.IV. 2009, V. Soon leg. [VS000006 and VS000007 pinned]. 10 specimens of Andrena vaga stylopized by females of $S$. melittae (one in each bee specimen) were collected: Tartu, near Kalmistu outcrop, 58 23'42"N 026 42'40”E, insect net, 25.III., 26.III., 30.III., 4.IV.2000, 1.IV.2008 and 5.IV., 9.IV.2010, V. Soon leg. [VS000008-VS000016, IZBE019-9004, pinned].

Widely distributed in Europe and extending to the Near East and North Africa. Among Estonian neighbouring countries, in Finland, Sweden and the North-western part of European Russia (Pohl 2010).

It is a typical parasite of many Andrena (Hymenoptera: Apidae) species (Kinzelbach 1978, Kathirithamby 1989). However, in Estonia only
Andrena vaga Panzer, 1799 has been recorded as its host. In early spring, flying male specimens of S. melittae, as well as stylopized Andrena bees, are not rare in sandy habitats near Tartu. In Estonia $A$. vaga is a widespread and common species, occurring wherever suitable habitat is present.

\section{Discussion}

All species recorded here are widely distributed in Europe and their presence in Estonia is unsurprising. However, despite the records and material listed above, the order Strepsiptera remains quite poorly studied in Estonia, and new country records and further details relating to host species and distributions can still be expected. For example, Halictoxenos spencei Perkins, 1918 is found in Finland and Paraxenos specidarum (Dufour, 1837) in Karelian Isthmus (the present Russian territory), and they may occur in Estonia. Some host species of these Strepsiptera recorded by Pekkarinen \& Raatikainen (1973) and Kinzelbach (1978) are common and widespread in Estonia. 


\section{Key to males of Strepsiptera in Baltic countries and Fennoscandia}

The key is compiled on the basis of Kinzelbach (1978), Kathirithamby (1989), Medvedev (1965) and Waloff (1981). Distribution of species is given by Pohl (2010), Pekkarinen \& Raatikainen (1973) and original data. Stenocranophilus anomalocerus (Pierce 1918) is included according to unpublished data from Latvia (cf. http:// leb.daba.lv/Strepsiptera.htm).

1. Tarsus 4-segmented

- Tarsus 2-3-segmented

2. Antenna 6-segmented, with flattened flabella on third segment (cf. Kinzelbach 1978: fig. 43; Medvedev 1965: fig. 171, 7). Large species: length $3.5-6 \mathrm{~mm}$. Parasitoid of Hymenoptera: Apidae (Andrena spp.)

Stylops melittae Kirby, 1802

[Norway, Sweden, Finland, NW Russia, Estonia]

- Antenna 4-segmented 3

3. Basis of maxilla flat. Postlumbium oval or semicircular (cf. Medvedev 1965: fig. 171, 5; Kinzelbach 1978: fig. 41, E)

- Basis of maxilla different. Postlumbium narrow and transversal (cf. Medvedev 1965: fig. 171, 6; Kinzelbach \& Pohl 2003: fig. 27, 4A)5

4. Scutum + prescutum of metathorax small. Length of metathorax less than $1.4 \mathrm{~mm}$. Aedeagus without hook. Parasitoid of Hymenoptera: Apidae (Halictus spp.)

Halictoxenos spencei Nassonow, 1893

[Norway, Finland]

- Scutum + prescutum of metathorax large. Length of metathorax 1.4-1.8 mm. Aedeagus with hook. Parasitoid of Hymenoptera: Apidae (Halictus (Seladonia) spp.)

Halictoxenos tumulorum Perkins, 1918

[Finland, NW Russia, Estonia]

5. Length $2-3.4 \mathrm{~mm}$. Flattened flabella on third antennal segment slightly longer than fourth segment of antenna (cf. Kinzelbach 1978: fig. 31, D). Prementum membraneous. Penultimate segment of palpus longer than apical segment (cf. Kinzelbach 1978: fig. 31, F). Parasitoid of Hymenoptera: Sphecidae

Paraxenos sphecidarum (Dufour, 1837)

[NW Russia]
- Length 4.4-5mm. Flattened flabella on third antennal segment shorter to equal than fourth segment of antenna (cf. Kinzelbach 1978: fig. 26, G). Prementum sclerotized. Penultimate segment of palpus shorter than apical segment (cf. Kinzelbach 1978: fig. 26, B). Parasitoid of Hymenoptera: Vespidae

Xenos vesparum Rossius, 1793 [Sweden]

6. Tarsus 3-segmented

7

- Tarsus 2-segmented (cf. Medvedev 1965: fig. 171,13). Antenna 5-segmented, only $3^{\text {rd }}$ segment with lateral flabellum (cf. Medvedev 1965: fig. 171,10; Kinzelbach 1978: fig. 22, A). Parasitoid of Hemiptera: Delphacidae

Elenchus tenuicornis (Kirby, 1815)

[Estonia, Norway, Sweden, Finland]

7. Antenna 7-segmented with lateral labellum on third to sixth segments. $R_{2}$ absent, base of $\mathrm{R}_{3}$ obsolete (cf. Waloff 1981: figs 20, 23). Parasitoid of Hemiptera: Ulopidae (Ulopa reticulata)

Halictophagus silwoodensis Waloff, 1981 [Estonia, (?)Finland] - Antenna 7-segmented with distinguishable lateral labellum on third and fourth segments. Wing with reduced venation; $R_{2}$ present, base of $\mathrm{R}_{3}$ distinct, point of radial furcation well beyond wing base (cf. Kinzelbach 1973: fig. 19). Parasitoid of Hemiptera: Delphacidae

Stenocranophilus anomalocerus (Pierce 1918) [Latvia, unpublished]

Acknowledgements. The study was funded by Estonian Science Foundation grant 7558 and 9174, targeted financing projects SF0170160s08 and SF0180122s08, and by the European Union through the European Regional Development Fund (Center of Excellence FIBIR). The Estonian Environmental Board is acknowledged for financing the Estonian Malaise traps project (2008-2011) and Mrs. Rita Miller for operating a particular trap in Hiiumaa Island. We are grateful to Dr. Jeyaraney Kathirithamby (Oxford, United Kingdom) and Dr. Antti Pekkarinen (Helsinki, Finland) for directing us to relevant literature. We would also like to thank Dr. John Davison (Tartu, Estonia), Dr. J. Kathirithamby and Dr. A. Pekkarinen for critical perusal of the manuscript with many helpful comments.

\section{References}

Abarenkov, K., Tedersoo, L., Nilsson, R. H., Vellak, K., Saar, I., Veldre, V., Parmasto, E., Prous, M., Aan, A., Ots, M., Kurina, O., Ostonen, I., Jõgeva, J., Halapuu, S., Põldmaa, K., Toots, M., Truu, J., Larsson, K.-H. \& 
Kõljalg, U. 2010: PlutoF - a web based workbench for ecological and taxonomic research, with an online implementation for fungal ITS sequences. - Evolutionary Bioinformatics 6: 189-196.

Bland, K. P. 1998: Halictophagus silwoodensis Waloff, 1981 (Strepsiptera: Halictophagidae) confirmed as a Scottish Insect. — Entomologist's record 110: 296297.

Elberg, K. 1995: The terrestrial invertebrates. — In: Raukas, A. (ed.), Estonia. Nature: 452-461. Valgus, Tallinn. [In Estonian.]

Henderickx, H. 2007: Overzicht van de Strepsiptera in België met vermelding van een nieuwe inheemse sort: Halictophagus silwoodensis (Halictophagidae). Phegae 35: 141-143.

Henderickx, H. 2008: Faunistische bemerkingen over Strepsiptera met onderzoek van een populatie Halictophagus silwoodensis (Halictophagidae) in het Nationaal Park Hoge Kempen (Maasmechelen). — Phegea 36: 103-107.

Jach, M. 2010: Fauna Europaea: Cicadomorpha. Fauna Europaea version 2.4, - [www document] URL http://www.faunaeur.org. (Site visited on 22 August, 2011)

Kathirithamby, J. 1989: Review of the Order Strepsiptera. - Systematic Entomology 14: 41-92.

Kathirithamby, J. 2002: Strepsiptera. Twisted-wing parasites. Version 24 September 2002 (under construction). - [www document] URL http://tolweb.org/Strepsiptera/8222/2002.09.24 in The Tree of Life Web Project, http://tolweb.org/. (Site visited on 11 August, 2011)

Kathirithamby, J. 2009: Host-Parasitoid Associations in Strepsiptera. - Annual Review of Entomology 54: 227-249

Kinzelbach, R. K. 1971: Morphologische Befunde an Fächerflüglern und ihre phylogenetische Bedeutung (Insecta: Strepsiptera). — Zoologica 41: 1-256 pp.

Kinzelbach, R. K. 1978: Fächerflügler (Strepsiptera). Die Tierwelt Deutschlands. 65. - VEB Gustav Fischer Verlag, Jena. 166 pp.
Kinzelbach R. K. \& Pohl, H. 2003: Ordnung Strepsiptera, Fächerflüger. - In: Dathe, H. H. (ed.), Wirbellose Tiere. 5. Teil: Insecta. 526-539. Spektrum Akademischer Verlag, Heidelberg-Berlin.

Maavara, V. 1956: The Manual of a young entomologist. — Eesti Riiklik Kirjastus, Tallinn. 276 pp. [In Estonian.]

Medvedev, L. N. 1965: (Order Strepsiptera.) — In: Bei-Bienko, G. Ya. (ed.), Key to the Insects of the European Part of the USSR. II. 641-645. Nauka, Leningrad. [In Russian.]

Melber, A. 1989: Die Parasitierung der Heidezikade Ulopa reticulata (F.) (Hom., Auchenorhyncha, Cicadellidae) durch Halictophagus silwoodensis Waloff(Strepsiptera, Halictophagidae) in nordwestdeutschen CallunaHeiden. - Braunschweiger Naturkundliche Schriften 3: 419-428.

Pekkarinen, A. \& Raatikainen, M. 1973: The Strepsiptera of Eastern Fennoscandia. — Notulae Entomologicae 53: $1-10$.

Pohl, H. 2010: Fauna Europaea: Strepsiptera. Fauna Europaea version $2.4-$ [www document] URL http://www.faunaeur.org. (Site visited on 12 August, 2011)

Smit, J. T. 2007: Het heidecicadewaaiertje Halictophagus silwoodensis nieuw voor Nederland (Strepsiptera: Halictophagidae). - Nederlandse Faunistische Mededelingen 27: 85-90.

Vilbaste, J. 1958: The fauna of cicadas in Estonian fens. Cand. Biol. Thesis. Institute of Zoology and Botany, Estonian Academy of Sciences. Tartu. 211 pp. [In Estonian.]

Vilbaste, J. 1971: The Estonian Cicadas I. — Valgus, Tallinn. 283 pp. [In Estonian with Russian and German summary.]

Waloff, N. 1981: The life history and description of Halictophagus silwoodensis n.sp. (Strepsiptera) and its host Ulopa reticulate (Cicadellidae) in Britain. - Systematic Entomology 6: 103-113. 